\title{
Faktor Reinforcing yang Berhubungan dengan Perilaku Remaja Ke Posyandu Remaja Kelurahan Penyengat Rendah Di Wilayah Puskesmas Aurduri Kota Jambi
}

\author{
Ruwayda $^{1 *}$, M. Dody Izhar $^{2}$ \\ ${ }^{1}$ Poltekkes Kemenkes Jambi \\ ${ }^{2}$ FKIK Unja \\ *Correspondence email: ruwayda@poltekkesjambi.ac.id, mdodyizhar@unja.ac.id
}

\begin{abstract}
Abstrak. Pendidikan kesehatan memiliki peranan penting untuk mengubah dan menguatkan faktor perilaku, mulai dari predisposisi, pendukung, hingga pendorong sehingga dapat menimbulkan perilaku positif dari masyarakat. Penyelenggaraan Posyandu remaja di Kota Jambi baru beberapa puskesmas, Data Puskesmas Aurduri tercatat jumlah yang berkunjung pada trimester I mencapai 100 orang (5\%) dari total 2005 remaja yang ada diwilayah Puskesmas. Pembentukan Posyandu remaja diharapkan dapat menjadi wadah untuk memfasilitasi remaja dalam memahami permasalahan kesehatan remaja, menemukan alternative pemecahan masalah, namun masih ada remaja yang tidak datang ke Posyandu remaja sehingga remaja banyak yang tidak mengetahui tentang kesehatannya. Desain penelitian analitik dengan rancangan cross sectional. Populasi adalah seluruh remaja di Puskesmas Aurduri kota Jambi. Sampel diambil melalui Quota Sampling sebanyak 92 responden,. Data dikumpulkan menggunakan kuesioner kemudian dianalisis secara univariat dan bivariat. Hasil penelitian diketahui (faktor reinforcing) 71 $(77,2 \%)$ peran petugas kesehatan baik, $56(60,9 \%)$ peran kader baik, $63(68,5 \%)$ dukungan keluarga baik dan sebanyak 75 (81.5\%) responden berperilaku baik. Hasil uji chi square menunjukkan ada hubungan peran petugas kesehatan, kader Posyandu remaja dan dukungan keluarga terhadap perilaku remaja ke posyandu $p$ value $=0.000(\mathrm{p}<0.05)$. Diharapkan adanya peningkatan anggaran, sarana prasarana fasilitas untuk meningkatkan kualitas pelayanan kesehatan terhadap remaja, selalu mencari inovasi baru agar meningkatkan minat remaja untuk datang ke Posyandu setiap bulannya.
\end{abstract}

Kata Kunci: Reinforcing; Perilaku; Posyandu Remaja

\begin{abstract}
Health education has an important role to change and strengthen behavioral factors, ranging from predisposing, supporting, to driving so that it can lead to positive behavior from the community. But there are still a few who organize youth Posyandu in Jambi City. Aurduri Health Center was the first to form a teen Posyandu. However, teenagers who visited trimester I reached $100(5 \%)$ was 2,005 teeneger. The formation of adolescent Posyandu is expected to be a place to facilitate adolescents in understanding adolescent health problems, find alternative solutions to problems, but there are still adolescents who do not come to adolescent Posyandu so that many adolescents do not know about their health. Design of analytical research with cross sectional design. The object of the study was all teenagers at the public health center Aurduri Jambi city. This study was conducted on February to July 2019. The samples used random sampling as many as 92 respondents. The collecting of data used a questionnaire then analyzed as univariate and bivariate analysis. The findings indicated that (the factors of reinforcing) 71 (77.2\%) the role of health personnel is good, 56 (60.9\%) the role of teen Posyandu cadres is good, 63 (68.5\%) good family support and as many as $75(81.5 \%)$ respondents had good behavior. The results of chi-square test indicated that there is correlation of the role of health personnel, teen Posyandu cadres and family support toward teen behavior to Posyandu $p$ value = 0.000 ( $p<0.05)$. It is expected that an increase in the budget, facilities and infrastructure to improve the quality of health services for adolescents, always seek innovation and new breakthroughs so that the interest of adolescents to come to teen POSYANDU increases every month.
\end{abstract}

Keywords: Reinforcing; Behavior; Teen Posyandu

\section{PENDAHULUAN}

Masa remaja merupakan masa Storm and stress, karena remaja mengalami banyak tantangan baik dari diri mereka sendiri (biopsychosocial factors) ataupun lingkungan (environmental factors). Apabila remaja tidak memiliki kemampuan untuk menghadapi berbagai tantangan tersebut, mereka dapat berakhir pada berbagai masalah kesehatan yang begitu kompleks sebagai akibat dari perilaku berisiko yang mereka lakukan (Rohaeti, 2018). Perilaku yang berisiko diantaranya HIV/AIDS, penyalahgunaan NAPZA, penyakit menular seksual, kehamilan yang tidak diinginkan/kehamilan di luar nikah. Berdasarkan Susenas tahun 2003, tingkat partisipasi anak sekolah SMP dan SMA laki-laki dan perempuan yang ke pelayanan kesehatan sebesar $65,4 \%$ (Kementerian RI, 2018). Permasalahan remaja juga bergantung pada perilakunya. Masalah pada remaja dapat diatasi dengan mengetahui faktor penyebabnya. Dengan diadakanya Posyandu remaja, maka remaja akan mendapatkan pelayanan kesehatan yang dibutuhkan dan pendidikan kesehatan maupun motivasi positif melalui konseling pada remaja yang memiliki masalah. Green ,1980 dalam Notoatmodjo,(2014) menyatakan bahwa pendidikan kesehatan memiliki peranan penting untuk 
mengubah dan menguatkan faktor perilaku, mulai dari predisposisi, pendukung, hingga pendorong sehingga dapat menimbulkan perilaku positif dari masyarakat.

Kondisi remaja di Indonesia saat ini dapat digambarkan sebagai berikut: Pernikahan usia remaja, Sex pranikah dan kehamilan tidak diinginkan, Aborsi 2,4 juta dan 700-800 ribu adalah remaja, MMR (Mortality Maternal Rate) 343/100.000 (17.000 per tahun, 1417 per bulan 47 perhari perempuan meninggal) karena komplikasi kehamilan dan persalinan, HIV/AIDS:1283 kasus, diperkirakan 52.000 terinfeksi (fenomena gunung es), 70\% remaja, Miras dan Narkoba (Kemenkes, 2018). Adapun hasil penelitian BNN bekerjasama dengan UI menunjukkan : jumlah penyalahguna narkoba sebesar $1,5 \%$ dari populasi atau 3,2 juta orang, terdiri dari $69 \%$ kelompok teratur pakai dan $31 \%$ kelompok pecandu dengan proporsi laki-laki sebesar $79 \%$, perempuan $21 \%$. Kelompok teratur pakai terdiri dari penyalahguna ganja $71 \%$, sabu $50 \%$, ekstasi $42 \%$ dan obat penenang $22 \%$. Kelompok pecandu terdiri dari penyalahguna ganja $75 \%$, heroin/putaw $62 \%$, shabu $57 \%$, ekstasi $34 \%$ dan obat penenang $25 \%$, panyalahguna Narkoba dengan suntikan (IDU) sebesar 56\% (572.000 orang) dengan kisaran 515.000 sampai 630.000 orang, beban ekonomi terbesar adalah untuk pembelian/konsumsi narkoba yaitu sebesar Rp.11,3 triliun (Kemenkes, 2018).

Berdasarkan hasil Survei Kesehatan Berbasis Sekolah di Indonesia tahun 2015 (GSHS) dapat terlihat gambaran faktor risiko kesehatan pada pelajar usia 12-18 tahun (SMP dan SMA) secara nasional. Sebanyak 41,8\% laki-laki dan $4,1 \%$ perempuan mengaku pernah merokok $32,82 \%$ di antara merokok pertama kali pada umur $\leq 13$ tahun. Data yang sama juga menunjukkan 14,4\% lakilaki dan $5,6 \%$ perempuan pernah mengkonsumsi alkohol, lalu juga didapatkan 2,6\% laki-laki pernah mengkonsumsi narkoba. Gambaran faktor risiko kesehatan lainnya adalah perilaku seksual dimana didapatkan $8,26 \%$ pelajar laki-laki dan $4,17 \%$ pelajar perempuan usia 12-18 tahun pernah melakukan hubungan seksual. Perilaku seks pranikah tentunya memberikan dampak yang luas pada remaja terutama berkaitan dengan penularan penyakit menular dan kehamilan tidak diinginkan serta aborsi. Laporan triwulan Direktorat Jenderal Pengendalian Penyakit dan Penyehatan Lingkungan (Ditjen P2PL) mulai 1987 sampai dengan Maret 2017 menunjukkan bahwa tingginya angka kejadian AIDS di kelompok usia 20-29 tahun mengindikasikan kelompok tersebut pertama kali terkena HIV pada usia remaja (Rohaeti, 2018)

Persentase Puskesmas menyelenggarakan kegiatan kesehatan remaja adalah sebesar 52,65\%. Jumlah tersebut mencapai target nasional yang sebesar $35 \%$. Namun demikian masih terdapat sepuluh provinsi $(32,4 \%)$ belum mencapai target Renstra tahun 2017. Hingga saat ini telah terdapat 5.173 Puskesmas PKPR yang siap memberikan pelayanan yang ramah remaja dan komprehensif tersebar di 34 provinsi di Indonesia (Kementerian RI, 2018:1). Kompleksnya permasalahan kesehatan pada remaja, tentunya memerlukan penanganan yang komprehensif dan terintegrasi yang melibatkan semua unsur dari lintas program dan sector terkait. Kebijakan bidang kesehatan terkait pelayanan kesehatan remaja sebagaimana dimaksud Permenkes Nomor 25 Tahun 2014 (Kemenkes, 2014) ditujukan agar setiap anak memiliki kemampuan berperilaku hidup bersih dan sehat, memiliki keterampilan hidup sehat, dan keterampilan sosial yang baik sehingga dapat belajar, tumbuh dan berkembang secara harmonis dan optimal menjadi sumber daya manusia yang berkualitas. Pelayanan Kesehatan Anak Usia Sekolah dan Remaja sebagaimana dimaksud pada Pasal 28 ayat 3 bahwa pelayanan itu dilakukan paling sedikit melalui: Usaha Kesehatan Sekolah (UKS) dan Pelayanan Kesehatan Peduli Remaja (PKPR). Pelayanan PKPR diberikan kepada semua remaja, dilaksanakan di dalam atau di luar gedung untuk perorangan atau kelompok. Pengembangan PKPR di Puskesmas sampai tahun 2017 sudah mencapai 5015 Puskesmas yang tersebar di 514 kabupaten/kota. Puskesmas PKPR memberikan layanan mulai dari KIE, konseling, pembinaan konselor sebaya, layanan klinis/medis dan rujukan serta pemberdayaan remaja dalam bentuk keterlibatan aktif dalam kegiatan kesehatan (Rohaeti, 2018).

Menurut penelitian yang dilakukan Saraswati (2010) dari hasil penelitian menunjukkan pengelolaan program Posyandu remaja meliputi kegiatan perencanaan, pengorganisasian, pelaksanaan dan pengawasan. Faktor pendukung keberhasilan program Posyandu remaja terdiri dari faktor pendukung internal meliputi kekompakan dari pengurus dan antusias dari remaja yang baik, sedangkan faktor pendukung eksternal yaitu adanya dukungan lintas sektor oleh pihak puskesmas. Faktor penghambat utama adalah masalah waktu, dan kekurangan SDM. Program pendidikan atau pelayanan pendidikan yang dilaksanakan dengan sasaran remaja tersebut diantaranya yaitu pelatihan Pendidik Sebaya (PS) dan Konselor Sebaya (KS), lifeskill atau keterampilan serta sosialisasi dan penyuluhan. Menurut penelitian yang dilakukan Rohmayanti (2015) dari hasil penelitian bahwa perspektif remaja tentang PKPR terdiri atas tiga tema. Pertama, persepsi remaja tentang keberadaan PKPR masih sangat variatif. Kedua, persepsi remaja tentang program PKPR yang diberikan pada remaja, bahwa dari 6 program PKPR belum semua diberikan. Ketiga, harapan remaja terhadap PKPR ke depan bahwa petugas kesehatan harus mampu memberikan penjelasan tentang masalah yang dialami remaja, berlaku seperti sahabat dan perlu melibatkan remaja, guru BP/UKS, orangtua serta masyarakat dalam pelayanan. Pelayanan dilakukan di tempat remaja berada, yang terjaga kerahasiaannya, waktu pelayanan 
menyesuaikan jam sekolah, perlu pemanfaatan sms, email untuk komunikasi dan informasi pada remaja.

Sedangkan penelitian menurut Sarweni (2017) dari hasil penelitian menunjukkan bahwa remaja membutuhkan kegiatan yang selalu memberikan inovasi, kegiatan tidak hanya bersifat kuratif namun lebih pada kegiatan yang bersifat promotive dan preventif seperti penyuluhan kesehatan remaja, edukasi dan sosialisasi. Data yang sama menunjukkanbahwa sekitar 23\% usia SMP dan $41 \%$ usia SMA tidak bersekolah, artinya mereka tidak mendapat pembinaan kesehatan seperti anak-anak yang bersekolah. Hal ini menunjukkan begitu besar jumlah remaja yang membutuhkan tempat yang dapat diakses dengan mudah untuk menyelesaikan dan mendiskusikan masalah kesehatannya selain dari fasilitas kesehatan yang sudah tersedia. Pembentukan Posyandu Remaja diharapkan dapat menjadi wadah untuk memfasilitasi remaja dalam memahami permasalahan kesehatan remaja, menemukan alternative pemecahan masalah, membentuk kelompok dukungan remaja, memperluas jangkauan Puskesmas PKPR, terutama bagi remaja daerah yang memiliki keterbatasan akses (Rohaeti, 2018). Konselor sebaya merupakan remaja aktif yang telah dilatih untuk melakukan kegiatan konseling bagi teman sebayanya. Hal ini berdasarkan kepada dasar dari kegiatan Posyandu remaja dimana remaja merupakan pelopor program kesehatan remaja. Kegiatan dalam Posyandu remaja harusnya dirancang dari remaja oleh remaja dan untuk remaja. Remaja yang telah terlatih konselor remaja akan dapat mendeteksi secara dini ketika terdapat permasalahan baik yang dialami sendiri maupun dialami oleh temannya. Kemampuan mendeteksi tersebut membuat remaja mampu melakukan pelaporan dan penyampaian kepada tenaga kesehatan yang ada, sehingga permaslahan bisa segera teratasi (Muthmainnah, 2013).

Data dari Dinas Kesehatan Kota Jambi (201\&), Puskesmas Aurduri jumlah remaja di Kelurahan Penyengat Rendah sebanyak 2.005 orang remaja, usia remaja (10-14 th) berjumlah 1.095 dengan laki-laki 571 orang dan perempuan 524 orang. Usia remaja (15-18 th) berjumlah 910 dengan laki-laki 464 orang dan perempuan 446 orang. Belum adanya kegiatan Posyandu Remaja di Kota Jambi, di Puskesmas Aurduri tercatat pertama yang membentuk Posyandu remaja. Survey awal yang dilakukan peneliti ke kader Posyandu remaja bahwa remaja yang berkunjung dari bulan Maret-Juli 2019 mencapai 100 (5\%) orang lebih setiap bulannya sedangkan jumlah remaja yang ada di Kelurahan Penyengat Rendah sebanyak 2.005 orang. Kader Posyandu Remaja yang ada di Penyengat Rendah berjumlah 7 orang, 1 orang di meja 1, 2 orang di meja 2 , 2 orang di meja 3, dan 2 orang di meja 4, pelayanan yang ada di Posyandu Remaja berupa pendaftaran, pemeriksaan antropometri/fisik, pengecekan anemia, pencatatan, konseling sesuai permasalahan, pemecahan masalah, pemberian tablet tambah darah, merujuk remaja ke fasilitas kesehatan jika diperlukan, dan kegiatan penyuluhan. Intinya kegiatan Posyandu remaja ini adalah untuk memperdayakan dan melibatkan remaja dalam menjaga kesehatannya dan merencanakan kehidupannya di masa yang akan datang. Hal ini masih ada remaja yang tidak datang ke Posyandu remaja sehingga remaja banyak yang tidak mengetahui tentang kesehatannya.

\section{METODE}

Penelitian ini dilakukan untuk mengetahui faktor Reinforcing yang berhubungan dengan perilaku remaja ke Posyandu. Penelitian ini menggunakan desain analitik dengan rancangan cross sectional dan menggunakan data primer yang didapat dari penyebaran kuesioner di Kelurahan Penyengat Rendah dan data sekunder yang diperoleh dari kader Posyandu dan Puskesmas Aurduri Kota Jambi Tahun 2019. Pelaksanaannya dilakukan pada bulan Februari sampai Juni tahun 2019 di Puskesmas Aurduri, Populasi dalam penelitian ini adalah seluruh remaja di Puskesmas Aurduri Kota Jambi tahun 2019.Sampel dalam penelitian ini menggunakan perhitungan sampel yang berjumlah 92 remaja dengan teknik Quota sampling. Instrument penelitian menggunakan kuesioner.Penelitian ini menggunakan analisis univariat dan bivariat.

\section{HASIL DAN PEMBAHASAN}

Dalam penelitian ini distribusi variabel responden yang diambil adalah gambaran faktor reinforcing (peran petugas, peran kader, dukungan keluarga) dengan perilaku remaja ke Posyandu remaja Kelurahan Penyengat Rendah di wilayah Puskesmas Aurduri Kota Jambi tahun 2019 yang didistribusikan dalam bentuk univariat yang bisa dilihat dalam tabel-tabel berikut ini:

\section{Distribusi Peran Petugas Kesehatan terhadap Perilaku Remaja}

Berdasarkan hasil penelitian melalui kuesioner diperoleh distribusiperan petugas kesehatan terhadap perilaku remaja yang dapat dilihat pada tabel sebagai berikut:

Tabel 1. Distribusi Peran Petugas Kesehatan terhadap Perilaku Remaja ke Posyandu Remaja Kelurahan Penyengat Rendah di Wilayah Puskesmas Aurduri Kota Jambi

\begin{tabular}{|c|c|c|c|c|c|}
\hline \multirow{3}{*}{ No } & \multirow{3}{*}{ Pernyataan } & \multicolumn{4}{|c|}{ Disrtibusi } \\
\hline & & \multicolumn{2}{|c|}{$\mathrm{Ya}$} & \multicolumn{2}{|c|}{ Tidak } \\
\hline & & f & $\%$ & $\mathrm{f}$ & $\%$ \\
\hline 1. & $\begin{array}{l}\text { Petugas kesehatan ikut berpartisipasi dalam pelaksanaan } \\
\text { Posyandu remaja setiap bulannya }\end{array}$ & 76 & 82.6 & 16 & 17.4 \\
\hline 2. & $\begin{array}{l}\text { Petugas kesehatan memberikan pelayanan kesehatan } \\
\text { dengan baik }\end{array}$ & 87 & 94.6 & 5 & 5.4 \\
\hline 3. & $\begin{array}{l}\text { Petugas kesehatan hadir dan memberikan penyuluhan } \\
\text { setiap Posyandu remaja }\end{array}$ & 76 & 82.6 & 16 & 17.4 \\
\hline 4. & $\begin{array}{l}\text { Sikap petugas kesehatan dalam memberikan konseling } \\
\text { sangat baik kepada remaja }\end{array}$ & 75 & 81.5 & 17 & 18.5 \\
\hline 5. & $\begin{array}{l}\text { Petugas kesehatan memberikan solusi dari masalah yang } \\
\text { dihadapi remaja. }\end{array}$ & 70 & 76.1 & 22 & 23.9 \\
\hline 6. & Petugas kesehatan hadir sebelum Posyandu remaja dimulai & 72 & 78.3 & 20 & 21.7 \\
\hline 7. & $\begin{array}{l}\text { Saat memberikan konseling petugas kesehatan } \\
\text { menggunakan bahasa yang mudah dimengerti }\end{array}$ & 74 & 80.4 & 18 & 19.6 \\
\hline 8. & Puas dengan pelayanan yang diberikan petugas kesehatan & 71 & 77.2 & 21 & 22.8 \\
\hline 9. & Nyaman ketika konseling dengan petugas kesehatan & 77 & 83.7 & 15 & 16.3 \\
\hline 10. & Petugas kesehatan memfasilitasi yang anda inginkan & 75 & 81.5 & 17 & 18.5 \\
\hline
\end{tabular}


Ruwayda dan M. Dody Izhar, Faktor Reinforcing yang Berhubungan dengan Perilaku Remaja Ke Posyandu Remaja Kelurahan Penyengat Rendah Di Wilayah Puskesmas Aurduri Kota Jambi

Tabel 1 menunjukkan distribusi responden berdasarkan peran petugas kesehatan yang mayoritas sebanyak $87(94,6 \%)$ orang menyatakan bahwa petugas kesehatan memberikan pelayanan kesehatan dengan baik, sebanyak $77(83,7 \%)$ orang menyatakan merasa nyaman ketika konseling dengan petugas kesehatan dan sebanyak $76(82,6 \%)$ orang menyatakan bahwa petugas kesehatan ikut berpartisipasi dalam pelaksanaan Posyandu remaja setiap bualnnya dan sebanyak 76 $(82,6 \%)$ orang menyatakan bahwa petugas kesehatan memberikan penyuluhan setiap Posyandu remaja. Namun masih ada sebanyak 22 (23,9\%) yang menyatakan bahwa petugas kesehatan tidak memberikan solusi dari masalah yang dihadapi remaja, sebanyak 21 $(22,8 \%)$ orang menyatakan bahwa tidak puas dengan pelayanan yang diberikan petugas kesehatan dan sebanyak $20(21,7 \%)$ orang menyatakan bahwa petugas kesehatan hadir sebelum Posyandu remaja dimulai.

Setelah dilakukan skoring pada pernyataan responden tersebut maka pernyataan tersebut dikelompokkan menjadi 2 yaitu peran petugas baik dan peran petugas kurang baik. Jika skor kurang dari nilai Median (8) maka dikategorikan peran petugas kurang baik, dan jika skor sama dengan atau lebih dari nilai Median (8) maka dikategorikan peran petugas baik. Untuk lebih jelasnya dapat dilihat pada gambar 1 di bawah ini

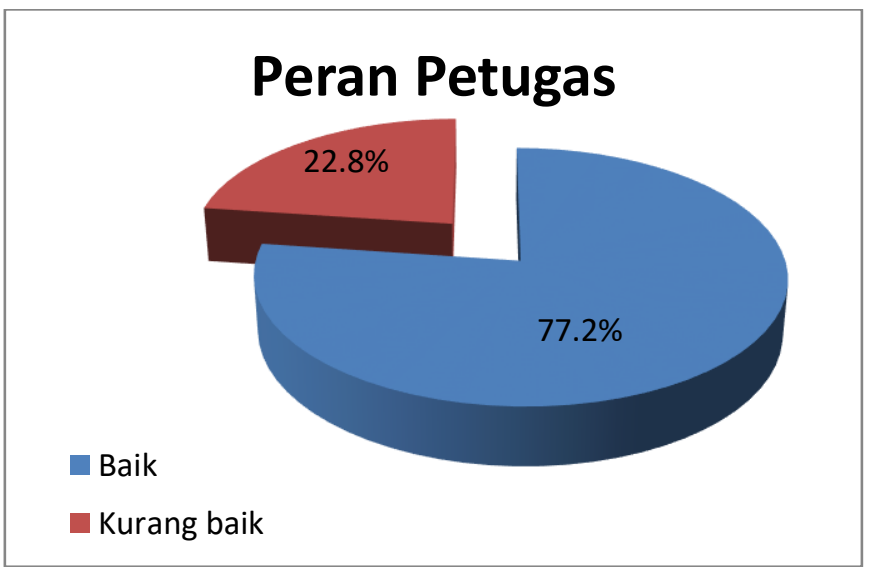

Gambar 1. Distribusi Peran Petugas Kesehatan terhadap

Perilaku Remaja ke Posyandu Remaja Kelurahan Penyengat

Rendah di Wilayah Puskesmas Aurduri Kota Jambi

Berdasarkan gambar 1 diatas, dapat diketahui bahwa sebanyak $71(77,2 \%)$ responden menyatakan bahwa peran petugas kesehatan baik terhadap perilaku remaja agar mau ke Posyandu remaja dan sebanyak 21 $(22,8 \%)$ responden menyatakan bahwa peran petugas kesehatan kurang baik terhadap perilaku remaja agar mau ke Posyandu remaja.

\section{Distribusi Peran Kader Posyandu terhadap Perilaku Remaja}

Berdasarkan hasil penelitian melalui kuesioner diperoleh distribusi peran kader Posyandu terhadap perilaku remaja yang dapat dilihat pada tabel sebagai berikut:

Tabel 2. Distribusi Peran Kader Posyandu terhadap Perilaku Remaja ke Posyandu Remaja Kelurahan Penyengat Rendah di Wilayah Puskesmas Aurduri Kota Jambi

\begin{tabular}{|c|c|c|c|c|c|}
\hline \multirow{3}{*}{ No } & \multirow{3}{*}{ Pernyataan } & \multicolumn{4}{|c|}{ Disrtibusi } \\
\hline & & \multicolumn{2}{|c|}{ Ya } & \multicolumn{2}{|c|}{ Tidak } \\
\hline & & f & $\%$ & $f$ & $\%$ \\
\hline 1. & $\begin{array}{l}\text { Kader berperan aktif dalam pelaksanaan Posyandu } \\
\text { Remaja }\end{array}$ & 75 & 81.5 & 17 & 18.5 \\
\hline 2. & $\begin{array}{l}\text { Partisipasi kader dalam setiap bulan pelaksanaan } \\
\text { Posyandu Remaja }\end{array}$ & 79 & 85.9 & 13 & 14.1 \\
\hline 3. & $\begin{array}{l}\text { Kader mengajak para remaja untuk ikut serta dalam } \\
\text { kegiatan Posyandu remaja }\end{array}$ & 74 & 80.4 & 18 & 19.6 \\
\hline 4. & $\begin{array}{l}\text { Kader memberikan konseling ke remaja yang } \\
\text { mengalami masalah }\end{array}$ & 67 & 72.8 & 25 & 27.2 \\
\hline 5. & $\begin{array}{l}\text { Kader melaksanakan tugasnya dalam pelaksanaan } \\
\text { Posyandu remaja }\end{array}$ & 72 & 78.3 & 20 & 21.7 \\
\hline 6. & Kader memberikan informasi tentang kesehatan remaja & 71 & 77.2 & 21 & 22.8 \\
\hline 7. & $\begin{array}{l}\text { Kader setiap bulannya selalu mengingatkan untuk hadir } \\
\text { ke Posyandu remaja }\end{array}$ & 67 & 72.8 & 25 & 27.2 \\
\hline 8. & Merasa nyaman jika konseling dengan kader & 69 & 75.0 & 23 & 25.0 \\
\hline 9. & Merasa puas dengan pelayanan yang diberikan kader & 74 & 80.4 & 18 & 19.6 \\
\hline 10. & Kader hadir sebelum kegiatan Posyandu remaja & 62 & 67.4 & 30 & 32.6 \\
\hline
\end{tabular}

Tabel 2 menunjukkan distribusi responden berdasarkan peran kader Posyandu yang mayoritas sebanyak $79(85.9 \%)$ orang menyatakan bahwa partisipasi kader dalam setiap bulan pelaksanaan Posyandu Remaja baik, dan sebanyak 75 (81.5\%) orang menyatakan kader berperan aktif dalam pelaksanaan Posyandu Remaja. Namun masih ada sebayak 30 (32.6\%) orang yang menyatakan bahwa tidak semua kader hadir sebelum kegiatan Posyandu remaja, dan sebanyak $25(27.2 \%)$ orang menyatakan bahwa kader tidak setiap bulannya mengingatkan untuk hadir ke Posyandu remaja dan sebanyak 25 (27,2\%) orang menyatakan bahwa kader memberikan konseling ke remaja yang mengalami masalah. Setelah dilakukan skoring pada pernyataan responden tersebut maka pernyataan tersebut dikelompokkan menjadi 2 yaitu peran kader baik dan peran kader kurang baik. Jika skor kurang dari nilai Median (8) maka dikategorikan peran kader kurang baik, dan jika skor sama dengan atau lebih dari nilai Median (8) maka dikategorikan peran kader baik. Untuk lebih jelasnya dapat dilihat pada gambar 2 di bawah ini:

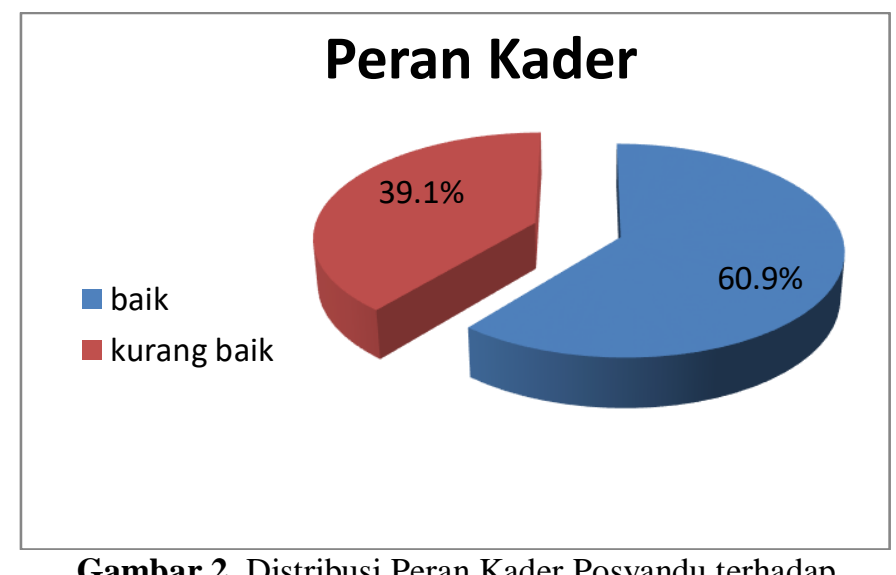

Gambar 2. Distribusi Peran Kader Posyandu terhadap Perilaku Remaja ke Posyandu Remaja Kelurahan Penyengat Rendah di Wilayah Puskesmas Aurduri Kota Jambi 
Berdasarkan gambar 2 diatas, dapat diketahui bahwa sebanyak 56 (60.9\%) responden menyatakan bahwa peran kader Posyandu baik terhadap perilaku remaja agar mau ke Posyandu remaja dan sebanyak 36 $(39,1 \%)$ responden menyatakan bahwa peran kader Posyandu kurang baik terhadap perilaku remaja agar mau ke Posyandu remaja.

\section{Distribusi Dukungan Keluarga terhadap Perilaku Remaja}

Berdasarkan hasil penelitian melalui kuesioner diperoleh distribusi dukungan keluarga terhadap perilaku remaja yang dapat dilihat pada tabel sebagai berikut:

Tabel 3. Distribusi Dukungan Keluarga terhadap Perilaku Remaja ke Posyandu Remaja Kelurahan Penyengat Rendah di Wilayah Puskesmas Aurduri Kota Jambi

\begin{tabular}{|c|c|c|c|c|c|}
\hline \multirow{3}{*}{ No } & \multirow{3}{*}{ Pernyataan } & \multicolumn{4}{|c|}{ Disrtibusi } \\
\hline & & \multicolumn{2}{|c|}{$\mathrm{Ya}$} & \multicolumn{2}{|c|}{ Tidak } \\
\hline & & f & $\%$ & f & $\%$ \\
\hline 1. & Keluarga mendukung kegiatan Posyandu Remaja & 89 & 96.7 & 3 & 3.3 \\
\hline 2. & $\begin{array}{l}\text { Keluarga mendukung anda untuk mengikuti kegiatan } \\
\text { Posyandu Remaja }\end{array}$ & 89 & 96.7 & 3 & 3.3 \\
\hline 3. & $\begin{array}{l}\text { Keluarga meminta remaja untuk hadir memeriksakan } \\
\text { kesehatan ke Posyandu remaja }\end{array}$ & 76 & 82.6 & 16 & 17.4 \\
\hline 4. & Keluarga memperhatikan setiap kegiatan yang anda lakukan & 75 & 81.5 & 17 & 18.5 \\
\hline 5. & Keluarga selalu menasehati anda tentang kesehatan & 76 & 82.6 & 16 & 17.4 \\
\hline 6. & Orangtua ikut serta mendampingi remaja datang ke Posyandu & 49 & 53.3 & 43 & 46.7 \\
\hline 7. & $\begin{array}{l}\text { Keluarga mengingatkan jadwal Posyandu remaja setiap } \\
\text { bulannya }\end{array}$ & 58 & 63.0 & 34 & 37.0 \\
\hline 8. & $\begin{array}{l}\text { Setelah selesai dari Posyandu remaja keluarga menanyakan } \\
\text { hasil dari pemeriksaan }\end{array}$ & 66 & 71.7 & 26 & 28.3 \\
\hline 9. & Keluarga memfasilitasi anda untuk ke Posyandu remaja & 67 & 72.8 & 25 & 27.2 \\
\hline 10. & $\begin{array}{l}\text { Dukungan keluarga sangat berperan dalam kegiatan Posyandu } \\
\text { Remaja }\end{array}$ & 85 & 92.4 & 7 & 7.6 \\
\hline
\end{tabular}

Tabel 3 menunjukkan distribusi responden berdasarkan dukungan keluarga yang mayoritas sebanyak 89 (96.7\%) orang menyatakan bahwa keluarga mendukung kegiatan Posyandu Remaja, sebanyak 89 (96,7\%) orang menyatakan bahwa keluarga mendukung anda untuk mengikuti kegiatan Posyandu remaja, dan sebanyak 85 (92.4\%) menyatakan keluarga sangat berperan dalam kegiatan Posyandu Remaja. Namun masih ada sebayak $43(47.6 \%)$ orang yang menyatakan bahwa orangtua tidak ikut serta mendampingi remaja datang ke Posyandu, sebanyak 34 (37\%) orang menyatakan bahwa keluarga tidak mengingatkan jadwal Posyandu remaja setiap bulannya dan sebanyak 26 $(28,3 \%)$ orang menyatakan bahwa setelah selesai dari Posyandu remaja, keluarga menanyakan hasil dari pemeriksaan.

Setelah dilakukan skoring pada pernyataan responden tersebut maka pernyataan tersebut dikelompokkan menjadi 2 yaitu dukungan keluargabaik dan dukungan keluarga kurang baik. Jika skor kurang dari nilai Median (8) maka dikategorikan dukungan keluarga kurang baik, dan jika skor sama dengan atau lebih dari nilai Median (8) maka dikategorikan dukungan keluarga baik. Untuk lebih jelasnya dapat dilihat pada gambar 3 di bawah ini:

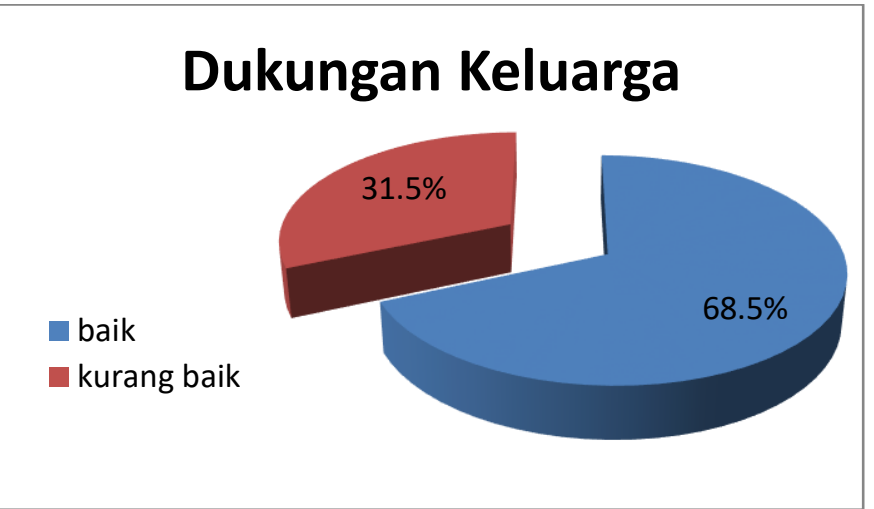

Gambar 3. Distribusi Dukungan Keluarga terhadap Perilaku Remaja ke PosyanduRemaja Kelurahan Penyengat Rendah di Wilayah Puskesmas Aurduri Kota Jambi

Berdasarkan gambar 3 diatas, dapat diketahui bahwa sebanyak $63(68.5 \%)$ responden menyatakan bahwa dukungan keluarga baik terhadap perilaku remaja agar mau ke Posyandu remaja dan sebanyak 29 (31,5\%) responden menyatakan bahwa dukungan keluarga kurang baik terhadap perilaku remaja agar mau ke Posyandu remaja

\section{Distribusi Perilaku Remaja}

Berdasarkan hasil penelitian melalui kuesioner diperoleh distribusi perilaku remaja yang dapat dilihat pada tabel sebagai berikut:

Tabel 4. Distribusi Perilaku Remaja ke Posyandu Remaja Kelurahan Penyengat Rendah di Wilayah Puskesmas Aurduri Kota Jambi

\begin{tabular}{cccc}
\hline \multirow{2}{*}{ No } & \multirow{2}{*}{ Perilaku } & \multicolumn{2}{c}{ Distribusi } \\
\cline { 3 - 4 } & & f & $\%$ \\
\hline 1 & Kurang Baik & 17 & $18.5 \%$ \\
2 & Baik & 75 & $81.5 \%$ \\
& Total & 92 & $100 \%$ \\
\hline
\end{tabular}

Berdasarkan tabel 4 dapat diketahui bahwa sebanyak $75(81.5 \%)$ responden menyatakan bahwa ikut berpatisipasi hadir ke pelayanan kesehatan di Posyandu Remaja dalam 1 tahun terakhir dan sebanyak 17 (18.5\%) responden menyatakan bahwa tidak ikut berpatisipasi hadir ke Pelayanan Kesehatan di Posyandu Remaja dalam 1 tahun terakhir.

Dalam penelitian ini distribusi variabel responden yang diambil adalah hubungan faktor reinforcing (peran petugas, peran kader, dukungan keluarga) dengan perilaku remaja ke Posyandu remaja Kelurahan Penyengat Rendah di wilayah Puskesmas Aurduri Kota Jambi tahun 2019 yang didistribusikan dalam bentuk uji statistik bivariat menggunakan uji chi square yang bisa dilihat dalam tabel-tabel berikut ini:

\section{Hubungan Peran Petugas Kesehatan dengan Perilaku Remaja ke Posyandu \\ Berdasarkan hasil uji statistik bivariat} menggunakan uji chi square diperoleh hasil hubungan 
Ruwayda dan M. Dody Izhar, Faktor Reinforcing yang Berhubungan dengan Perilaku Remaja Ke Posyandu Remaja Kelurahan Penyengat Rendah Di Wilayah Puskesmas Aurduri Kota Jambi

peran petugas dengan perilaku remaja yang dapat dilihat pada tabel sebagai berikut :

Tabel 5. Distribusi Hubungan Peran Petugas Kesehatan dengan Perilaku Remaja Ke Posyandu Remaja Kelurahan Penyengat Rendah di Wilayah Puskesmas Aurduri Kota Jambi

\begin{tabular}{|c|c|c|c|c|c|c|c|}
\hline \multirow{3}{*}{$\begin{array}{c}\text { Peran Petugas } \\
\text { Kesehatan }\end{array}$} & \multicolumn{4}{|c|}{ Perilaku Remaja } & \multirow{2}{*}{\multicolumn{2}{|c|}{ Total }} & \multirow{3}{*}{$\begin{array}{c}\text { P-Value } \\
\text { OR }(95 \% \mathrm{CI})\end{array}$} \\
\hline & \multicolumn{2}{|c|}{ Kurang Baik } & \multicolumn{2}{|c|}{ Baik } & & & \\
\hline & f & $\%$ & f & $\%$ & $f$ & $\%$ & \\
\hline Kurang baik & 11 & 52,4 & 10 & 47,6 & 21 & 100 & \\
\hline Baik & 6 & 8,5 & 65 & 91,5 & 71 & 100 & (3.6- \\
\hline Jumlah & 17 & 18,5 & 75 & 81,5 & 92 & 100 & 89,4 \\
\hline
\end{tabular}

Tabel 5 menunjukkan bahwa dari 21 responden yang menyatakan peran petugas kurang baik, sebanyak $11(52,4 \%)$ perilaku remajanya kurang baik dalam mengikuti kegiatan Posyandu remaja. Dan dari 71 responden yang menyatakan peran petugas baik sebanyak $65(91,5 \%)$ perilaku remajanya baik dalam mengikuti kegiatan Posyandu remaja.

Hasil analisis uji chi square diperoleh hasil $p$ value $=0.000(\mathrm{p}<0.05)$ yang berarti $(\mathrm{H} 0)$ ditolak maka (Ha) gagal ditolak sehingga diartikan bahwa ada hubungan peran petugas kesehatan dengan perilaku remaja ke Posyandu remaja Kelurahan Penyengat Rendah di wilayah Puskesmas Aurduri Kota Jambi tahun 2019.

\section{Hubungan Perilaku Remaja ke Posyandu dengan Peran Kader}

Berdasarkan hasil uji statistik bivariat menggunakan uji chi square diperoleh hasil hubungan peran kader Posyandu remaja dengan perilaku remaja yang dapat dilihat pada tabel 5.6 sebagai berikut:

Tabel 6. Distribusi Hubungan Peran Kader Posyandu remaja dengan Perilaku Remaja Ke Posyandu remaja Kelurahan

Penyengat Rendah di Wilayah Puskesmas Aurduri Kota Jambi

\begin{tabular}{|c|c|c|c|c|c|c|c|}
\hline \multirow{3}{*}{$\begin{array}{c}\text { Peran Kader } \\
\text { Posyandu }\end{array}$} & \multicolumn{4}{|c|}{ Perilaku Remaja } & \multirow{2}{*}{\multicolumn{2}{|c|}{ Total }} & \multirow{3}{*}{$\begin{array}{c}\text { P-Value } \\
\text { OR }(95 \% \mathrm{CI})\end{array}$} \\
\hline & \multicolumn{2}{|c|}{ Kurang Baik } & \multicolumn{2}{|c|}{ Baik } & & & \\
\hline & $\mathrm{F}$ & $\%$ & $f$ & $\%$ & $\mathrm{f}$ & $\%$ & \\
\hline Kurang baik & 15 & 41,7 & 21 & 58,3 & 36 & 100 & \\
\hline Baik & 2 & 3,6 & 54 & 96,4 & 56 & 100 & 0.000 \\
\hline Jumlah & 17 & 18,5 & 75 & 81,5 & 92 & 100 & \\
\hline
\end{tabular}

Tabel 6 menunjukkan bahwa dari 36 responden yang menyatakan peran kader kurang baik, sebanyak 15 $(41,7 \%)$ perilaku remajanya kurang baik dalam mengikuti kegiatan Posyandu Remaja. Dan dari 56 responden menyatakan peran kader baik sebanyak 54 $(96,4 \%)$ perilaku remajanya baik dalam mengikuti kegiatan Posyandu Remaja.

Hasil analisis uji chi square diperoleh hasil $p$ value $=0.000(\mathrm{p}<0.05)$ yang berarti $(\mathrm{H} 0)$ ditolak maka (Ha) gagal ditolak sehingga diartikan bahwa ada hubungan peran kader Posyandu remaja dengan perilaku remaja ke Posyandu remaja Kelurahan Penyengat Rendah di wilayah Puskesmas Aurduri Kota Jambi tahun 2019.

\section{Hubungan Perilaku Remaja ke Posyandu dengan Dukungan Keluarga}

Berdasarkan hasil uji statistik bivariat menggunakan uji chi square diperoleh hasil hubungan dukungan keluarga dengan perilaku remaja yang dapat dilihat pada tabel 7 sebagai berikut:

Tabel 7. Distribusi Hubungan Dukungan Keluarga dengan Perilaku Remaja Ke Posyandu remaja Kelurahan Penyengat Rendah di Wilayah Puskesmas Aurduri Kota Jambi

\begin{tabular}{|c|c|c|c|c|c|c|c|}
\hline \multirow{3}{*}{$\begin{array}{l}\text { Dukungan } \\
\text { Keluarga }\end{array}$} & \multicolumn{4}{|c|}{ Perilaku Remaja } & \multirow{2}{*}{\multicolumn{2}{|c|}{ Total }} & \multirow{3}{*}{$\begin{array}{c}\text { P-Value } \\
\text { OR }(95 \% \mathrm{CI})\end{array}$} \\
\hline & \multicolumn{2}{|c|}{ Kurang Baik } & \multicolumn{2}{|c|}{ Baik } & & & \\
\hline & $\mathrm{f}$ & $\%$ & $f$ & $\%$ & $f$ & $\%$ & \\
\hline Kurang baik & 13 & 44,8 & 16 & 55,2 & 29 & 100 & \\
\hline Baik & 4 & 6,3 & 59 & 93,7 & 63 & 100 & $(3436-41806)$ \\
\hline Jumlah & 17 & 18,5 & 75 & 81,5 & 92 & 100 & \\
\hline
\end{tabular}

Tabel 7 menunjukkan bahwa dari 29 responden yang menyatakan dukungan keluarga kurang baik, sebanyak $13(44,8 \%)$ perilaku remajanya kurang baik dalam mengikuti kegiatan Posyandu Remaja. Dan dari 63 responden yang menyatakan dukungan keluarga baik sebanyak $59(93,7 \%)$ perilaku remaja baik dalam mengikuti kegiatan Posyandu remaja.

Hasil analisis uji chi square diperoleh hasil $p$ value $=0.000(\mathrm{p}<0.05)$ yang berarti $(\mathrm{H} 0)$ ditolak maka (Ha) gagal ditolak sehingga diartikan bahwa ada hubungan dukungan keluarga dengan perilaku remaja ke Posyandu remaja Kelurahan Penyengat Rendah di wilayah Puskesmas Aurduri Kota Jambi tahun 2019.

\section{Pembahasan}

Gambaran peran petugas dengan perilaku remaja ke Posyandu remaja Kelurahan Penyengat Rendah di wilayah Puskesmas Aurduri Kota Jambi

Hasil penelitian menunjukkan bahwa $77,2 \%$ responden menyatakan bahwa ada peran petugas kesehatan yang mendorong remaja untuk hadir dalam kegiatan Posyandu remaja. Bentuk peran petugas kesehatan umumnya berupa memberikan pelayanan kesehatan yang baik, memberikan konseling remaja dan memfasilitasi keinginan remaja.

Berdasarkan hasil penelitian diketahui bahwa ada peran petugas kesehatan yang mendorong remaja untuk hadir dalam kegiatan Posyandu remaja. Dan masih ada responden yang menyatakan petugas kesehatan kurang baik dalam mendorong remaja untuk hadir di kegiatan Posyandu Remaja, seharusnya petugas lebih giat lagi dalam mendorong remaja untuk ikut kegiatan Posyandu remaja agar kembali datang ke Posyandu remaja lagi setiap bulannya.

Menurut penelitian yang dilakukan Saraswati (2010) dari hasil penelitian menunjukkan pengelolaan program Posyandu remaja meliputi kegiatan perencanaan, pengorganisasian, pelaksanaan dan pengawasan. Faktor pendukung keberhasilan program Posyandu remaja terdiri dari faktor pendukung internal meliputi kekompakan dari pengurus dan antusias dari 
remaja yang baik, sedangkan faktor pendukung eksternal yaitu adanya dukungan lintas sektor oleh pihak puskesmas. Faktor penghambat utama adalah masalah waktu, dan kekurangan SDM. Program pendidikan atau pelayanan pendidikan yang dilaksanakan dengan sasaran remaja tersebut diantaranya yaitu pelatihan Pendidik Sebaya (PS) dan Konselor Sebaya (KS), lifeskill atau keterampilan serta sosialisasi dan penyuluhan.

Petugas kesehatan adalah setiap orang yang mengabdikan diri dalam bidang kesehatan serta memiliki pengetahuan dan/atau keterampilan melalui pendidikan di bidang kesehatan yang untuk jenis tertentu memerlukan kewenangan untuk melakukan upaya kesehatan

Gambaran peran kader Posyandu dengan perilaku remaja ke Posyandu remaja Kelurahan Penyengat Rendah di wilayah Puskesmas Aurduri Kota Jambi

Ada sebanyak $60,9 \%$ responden juga menyatakan bahwa ada peran dari kader Posyandu kepada remaja untuk datang ke Posyandu mengikuti kegiatan Posyandu Remaja. Bentuk peran dari kader tersebut berupa pelaksanaan Posyandu setiap bulan, selalu aktif, selalu mengajak dan memberikan kepuasan dalam setiap pelayanan.

Berdasarkan hasil penelitian diketahui bahwa peran kader Posyandu baik kepada remaja untuk datang ke Posyandu mengikuti kegiatan Posyandu Remaja. Kader berperan aktif dalam kegiatan Posyandu Remaja maka kader harus mempunyai cara atau inovasi agar remaja tertarik ke Posyandu Remaja setiap Bulannya dan kader memiliki ilmu yang dapat memberikan kepuasan dan kenyamanan saat konseling.

Sedangkan penelitian menurut Sarweni (2017) dari hasil penelitian menunjukkan bahwa remaja membutuhkan kegiatan yang selalu memberikan inovasi, kegiatan tidak hanya bersifat kuratif namun lebih pada kegiatan yang bersifat promotive dan preventif seperti penyuluhan kesehatan remaja, edukasi dan sosialisasi.

Kader Kesehatan Remaja yang dimaksud adalah remaja yang dipilih/secara sukarela mengajukan diri dan dilatih untuk ikut melaksanakan upaya pelayanan kesehatan remaja bagi diri sendiri, teman sebaya, keluarga serta masyarakat.

\section{Gambaran dukungan keluargadengan perilaku remaja ke Posyandu remaja Kelurahan Penyengat Rendah di wilayah Puskesmas Aurduri Kota Jambi}

Selanjutnya sebanyak $68,5 \%$ responden juga menyatakan mendapatkan dukungan dari keluarga untuk ikut dalam setiap kegiatan Posyandu remaja yang dilakukan. Bentuk dukungan keluarga umumnya berupa ikut serta hadir, memberikan nasehat dan mendukung segala bentuk aktivitas yang dilakukan.

Berdasarkan hasil penelitian diketahui bahwa dukungan keluarga untuk ikut dalam setiap kegiatan
Posyandu Remaja yang dilakukan baik. Seharusnya keluarga mendampingi remaja saat ke Posyandu Remaja karena dukungan keluarga sangat penting terhadap kesehatan remaja, dan keluarga mengetahui kesehatan dan permasalahan anak remajanya.

Sejalan dengan penelitian Saraswati (2010) bahwa faktor pendukung keberhasilan program Posyandu remaja terdiri dari faktor pendukung internal meliputi kekompakan dari pengurus dan antusias dari remaja yang baik, sedangkan faktor pendukung eksternal yaitu adanya dukungan lintas sektor oleh pihak puskesmas. Faktor penghambat utama adalah masalah waktu, dan kekurangan SDM.Sesuai dengan tujuan dibentuknya Posyandu remaja, maka sudah sepantasnya mendapatkan dukungan dari berbagai pihak. Masih ada yang merasa kurang mendukung, itu adalah yang normal, karena kesibukan individu terutama petugas kesehatan yang juga melayani jenis pelayanan kesehatan kepada semua kalangan seperti lansia, balita dan ibu hamil serta ibu nifas.

Posyandu Remaja merupakan salah satu bentuk Upaya Kesehatan Bersumber Daya Masyarakat (UKBM) yang dikelola dan diselenggarakan dari, oleh, untuk dan bersama masyarakat termasuk remaja dalam penyelenggaraan pembangunan kesehatan, guna memberdayakan masyarakat dan memberikan kemudahan dalam memperoleh pelayanan kesehatan bagi remaja untuk meningkatkan derajat kesehatan dan keterampilan hidup sehat remaja (Rohaeti, 2018).

Jadwal Posyandu yang dilakukan setiap bulan menyesuaikan waktu dari peserta dan petugas. Antusias peserta Posyandu remaja yang tergolong tinggi sesuai dengan hasil penelitan, menuntut adanya perbaikan dan inovasi dalam setiap prosesnya agar lebih banyak remaja yang tertarik dan ikut hadir untuk mendapatkan pelayanan. Begitupun dengan pengelolaan program harus semakin baik agar program Posyandu dapat terus berjalan kearah yang lebih baik serta memberikan manfaat kepada setiap remaja.

\section{Hubungan Peran Petugas dengan Perilaku Remaja KePosyandu Remaja Kelurahan Penyengat Rendah di Wilayah Puskesmas Aurduri Kota Jambi}

Hasil penelitian menunjukkan bahwa ada hubunganperilaku remaja ke Posyandu dengan peran petugas kesehatan Kelurahan Penyengat Rendah di wilayah Puskesmas Aurduri Kota Jambi tahun 2019. Hasil ini didukung dengan $p$ value $=0.000(\mathrm{p}<0.05)$ yang berarti (H0) ditolak atau (Ha) gagal ditolak. Petugas kesehatan berperan sangat baik dinyatakan oleh lebih dari $91 \%$ responden.

Berdasarkan hasil penelitian diketahui bahwa ada hubungan perilaku remaja ke Posyandu dengan peran petugas kesehatan kelurahan Penyengat Rendah di wilayah Puskesmas Aurduri Kota Jambi tahun 2019.Hal ini petugas kesehatan belum maksimal dalam mengajak 
remaja dan belum mencakup ke semua remaja yang ada.Sehingga masih ada remaja yang tidak hadir di kegiatan Posyandu Remaja.

Hasil penelitian ini didukung oleh Mukti (2012) bahwa kehadiran petugas kesehatan di Posyandu akan meningkatkan jumlah kunjungan kelompok sasaran seperti ibu balita dan remaja ke Posyandu lebih dari 70\%. Penelitian ini diadakan di Posyandu di Kelurahan Wonokarto, Kecamatan Wonogiri, kabupaten Wonogiri tahun 2012. Kehadiran petugas kesehatan dalam setiap kegiatan Posyandu merupakan bentuk peran yang nyata untuk meningkatkan jumlah kunjungan kelompok sasaran. Peran petugas kesehatan yang sangat dibutuhkan oleh remaja antara lain seperti pemeriksaan kesehatan berupa pemerikasaan tekanan darah, konseling dan nasehat bagi remaja. Selain itu petugas kesehatan juga memberikan konseling yang terkait masalah kesehatan.

Pelayanan Kesehatan Remaja di Posyandu adalah pelayanan kesehatan yang peduli remaja, mencakup upaya promotif dan preventif, meliputi: Keterampilan Hidup Sehat (PKHS), kesehatan reproduksi remaja, kesehatan jiwa dan pencegahan penyalahgunaan Napza, Gizi, Aktivitas fisik, pencegahan Penyakit Tidak Menular (PTM) dan Pencegahan kekerasan pada remaja (Rohaeti, 2018). Dalam memberikan pelayanan petugas selain dituntut sesuai dengan tujuan dan memiliki target pencapaian, juga harus menjalin rasa kekeluargaan kepada remaja agar antusiame tetap terjaga sehingga program Posyandu remaja dapat diterima dengan baik.

\section{Hubungan Peran Kader Posyandu dengan Perilaku Remaja KePosyandu Remaja Kelurahan Penyengat Rendah di Wilayah Puskesmas Aurduri Kota Jambi Tahun 2019}

Hasil penelitian menunjukkan bahwa ada hubungan perilaku remaja ke Posyandu dengan peran kader Posyandu Kelurahan Penyengat Rendah di wilayah Puskesmas Aurduri Kota Jambi tahun 2019. Hasil ini didukung dengan $p$ value $=0,000(\mathrm{p}<0.05)$ yang berarti (H0) ditolak maka (Ha) gagal ditolak. Peran kader Posyandu remaja baik dinyatakan oleh 96,4\% responden.

Berdasarkan hasil penelitian diketahui bahwa ada hubungan perilaku remaja ke Posyandu dengan peran kader Posyandu remaja kelurahan Penyengat Rendah di wilayah Puskesmas Aurduri Kota Jambi tahun 2019. Kader Posyandu Remaja melakukan inovasi dalam kegiatan Posyandu Remaja seperti adanya kuis, permainan, atau kegiatan lain untuk menambah ilmu para remaja dan membuat remaja tertarik kembali untuk datang ke Posyandu Remaja setiap bulannya.

Hasil penelitian Hasanah (2014) menunjukkan bahwa keaktifan kader dalam kegiatan Posyandu di wilayah kerja Puskesmas Palasari Kecamatan Ciater Kabupaten Subang (p-value: 0,00). Salah satu yang mempengaruhi keaktifan kader Posyandu adalah pekerjaan kader. Pekerjaan merupakan suatu kegiatan atau aktivitas seseorang untuk memperoleh penghasilan guna memenuhi kebutuhan hidup sehari-hari.Pekerjaan mempengaruhi seseorang terhadap peran serta masyarakat meliputi keadaan waktu yang tersedia untuk kegiatan sosial. Semakin sedikit waktu seseorang untuk bersosialisasi karena banyaknya pekerjaan menyebabkan menurunnya tingkat kesadaran dan tanggung jawab mereka terhadap kegiatan sosial, salah satunya adalah peranan aktif menjadi kader kesehatan di lingkungan.

Kader Kesehatan Remaja yang dimaksud adalah remaja yang dipilih/secara sukarela mengajukan diri dan dilatih untuk ikut melaksanakan upaya pelayanan kesehatan remaja bagi diri sendiri, teman sebaya, keluarga serta masyarakat (PP 2018). Kader juga anggota masyarakat yang dipilih dari oleh masyarakat tersebut dan mau serta mampu bekerja secara sukarela. Kader juga mempunyai waktu untuk bekerja bagi remaja lainya disamping mereka memiliki kesibukan sendiri. Keberadaan kader merupakan bentuk peran serta remaja dan merupakan indikator partisipasi remaja khususnya dalam bidang kesehatan remaja, sehingga keberadaan kader dalam pencapaian tujuan Posyandu sangat berperan penting.

\section{Hubungan Dukungan Keluarga dengan Perilaku Remaja KePosyandu Remaja Kelurahan Penyengat Rendah di Wilayah Puskesmas Aurduri Kota Jambi}

Hasil penelitian menunjukkan bahwa ada hubungan perilaku remaja ke Posyandu dengan dukungan keluarga Kelurahan Penyengat Rendah di wilayah Puskesmas Aurduri Kota Jambi tahun 2019. Hasil ini didukung dengan $p$ value $=0,000(\mathrm{p}<0.05)$ yang berarti (H0) ditolak maka (Ha) gagal ditolak. Dukungan Keluarga Posyandu remaja baik dinyatakan oleh 93,7\% responden.

Berdasarkan hasil penelitian diketahui bahwa ada hubunganperilaku remaja ke Posyandu dengan dukungan keluarga Kelurahan Penyengat Rendah di wilayah Puskesmas Aurduri Kota Jambi tahun 2019. Dukungan keluarga sangat penting bagi pertumbuhan remaja, dukungan keluarga berupa dukungan emosional, dukungan informasi, dan dukungan penghargaan terhadap yang dilakukan remaja tersebut.

Dukungan keluarga dapat berupa sikap peduli, tindakan berupa mengingatkan dan penerimaan keluarga terhadap kesalahan yang telah dilakukan. Hal ini juga sejalan dengan BKKBN (2000) bahwa dukungan dari anggota keluarga dan teman terdekat merupakan salah satu dukungan yang sangat diperlukan terhadap pelaksanaan kegiatan Posyandu remaja dan berpengaruh besar bagi remaja untuk memacu semangat dalam memeriksakan diri sejak dini. Selain itu dukungan keluarga terutama dalam konteks hubungan saudara atau hubungan orang tua sebagai keluarga inti merupakan 
sumber dukungan yang paling penting. Dengan adanya dukungan keluarga diharapkan remaja dapat memahami masalahnya, memberikan perhatian yang diperlukan merupakan motivasi yang baik bagi remaja.

Dukungan keluarga adalah suatu bentuk hubungan interpersonal yang melindungi seseorang dari efek stress yang buruk (Kaplan dan Sadock, 2002). Dukungan keluarga menurut Friedman (2010) adalah sikap, tindakan penerimaan keluarga terhadap anggota keluarganya, berupa dukungan informasional dukungan penilaian, dukungan instrumental dan dukungan emosional. Perubahan fisiologis tersebut, harus dikelola dengan baik agar remaja tidak terjerumus pada hal-hal negatif. Bisa jadi karena faktor inilah kebanyakan keluarga yang memiliki remaja berusaha memberikan dukungan agar nilai nilai sosial dan kesehatan remaja dapat diketahui dan dipahami dengan baik.

\section{SIMPULAN}

1. Sebagian $71(77,2 \%)$ responden menyatakan bahwa peran petugas kesehatan terhadap perilaku remaja ke Posyandu remaja, namun sebagian 21 (22,8\%) responden menyatakan bahwa peran petugas kesehatan kurang baik terhadap perilaku remaja agar mau ke Posyandu remaja.

2. Sebagian $56(60.9 \%)$ menyatakan bahwa ada peran kader Posyandu terhadap perilaku remaja ke Posyandu remaja, namun sebagian $36 \quad(39,1 \%)$ responden menyatakan bahwa perankader Posyandu kurang baik terhadap perilaku remaja agar mau ke Posyandu remaja.

3. Sebagian 63 (68.5\%) menyatakan bahwa ada dukungan keluarga terhadap perilaku remaja ke Posyandu remaja dan sebagian 75 (81.5\%) responden menyatakan ikut berpatisipasi hadir ke Posyandu Remaja dalam 1 tahun terakhir, namun sebagian 29 $(31,5 \%)$ responden menyatakan bahwa dukungan keluarga kurang baik terhadap perilaku remaja agar mau ke Posyandu remaja.

4. Ada hubungan peran petugas kesehatan $p$ value $=$ $0.000(\mathrm{p}<0.05)$, Ada hubungan peran kader Posyandu $p$ value $=0.000(\mathrm{p}<0.05)$. Ada hubungan dukungan keluarga $p$ value $=0.000(\mathrm{p}<0.05)$ dengan perilaku remaja ke Posyandu di wilayah Puskesmas Aurduri Kelurahan Penyengat Rendah Kota Jambi.

\section{DAFTAR PUSTAKA}

BKKBN, 2010. Panduan Praktis Pelayanan Kontrasepsi, Jakarta

Dinas Kesehatan Kota Jambi , 2017, Data Profel Kesehatan Kota Jambi

Friedman, G, 2010. Buku Ajar Keperawatan Keluarga: Riset, teori dan Praktik, Edisi Ke-5 Jakarta, EGC

Hasanah, Ruyatul. 2014. Faktor-Faktor yang berhubungan dengan keaktifan kader dalam kegiatan POSYANDU (Studi di Puskesmas Palasari Kabupaten Subang).

Kaplan \& Sadock. (2002). Sinopsis psikiatri jilid2.

(Edisi 7). Jakarta: Binarupa Aksara.

Kementerian Kesehatan RI. 2018. Panduan PKPR. Jakarta: Kementerian Kesehatan.

Kementerian Kesehatan RI. 2014. Petunjuk Teknis Pelaksanaan Pelayanan Kesehatan Reproduksi Terpadu di Tingkat Pelayanan Kesehatan Dasar. Jakarta: Kementerian Kesehatan.

Mukti, Aji Herwinda. 2012. Faktor-Faktor yang berhubungan dengan perilaku ibu menimbangkan balita ke posyandu di Kelurahan Wonokarto Kecamatan Wonogiri Kabupaten Wonogiri. Depok: Universitas Indonesia.

Muthmainnah. 2013. Analisis Stakeholder Remaja terhadap implementasi Program Pelayanan Kesehatan Peduli Remaja (PKPR) di Kota Semarang. Promosi Kesehatan, Volume I, pp 170183.

Notoadmodjo, Soekidjo. 2014. Ilmu Perilaku Kesehatan. Jakarta : Rineka Cipta.

Rohmayanti. 2015. Pelayanan Kesehatan peduli remaja menurut perspektif remaja di Kota Magelang.

Rohaeti, S, Linda. 2018. Petunjuk Teknis Penyelenggaraan Posyandu Remaja. Jakarta: Kemenkes RI.

Saraswati, Dea Rizkiana. 2010. Pengelolaan program POSYANDU remaja di pusat informasi dan konseling remaja (PIK-R) Semarak Ngemplak. Sleman Yogyakarta.

Sarweni, Kinanty Putri. 2017. Demand VS Supply Program Kesehatan Remaja Di Puskesmas Tanah Kalikedinding Surabaya: Universitas Airlangga. 